Scientia Marina 74(2)

June 2010, 223-233, Barcelona (Spain)

ISSN: 0214-8358

doi: $10.3989 /$ scimar.2010.74n2223

\title{
Diet, growth and reproduction of four flatfishes on the Portuguese coast
}

\author{
CÉLIA M. TEIXEIRA, MARISA I. BATISTA and HENRIQUE N. CABRAL \\ Universidade de Lisboa, Faculdade de Ciências, Centro de Oceanografia, Campo Grande, 1749-016 Lisboa, Portugal. \\ E-mail: cmteixeira@fc.ul.pt
}

\begin{abstract}
SUMMARY: Four flatfish species were collected between January 2003 and June 2005 from commercial fishing vessels operating with gill nets and bottom trawls along the Portuguese coast in order to examine feeding habits, age and growth and reproduction. Citharus linguatula (Linnaeus, 1758), Lepidorhombus boscii (Risso, 1810) and Microchirus azevia (de Brito Capello, 1867) fed mainly on crustaceans, whereas Platichthys flesus (Linnaeus, 1758) fed mainly on echinoderms and crustaceans. Feeding activity was highest in spring and summer; females and small individuals showed the lowest vacuity index values. For all the species, significant differences were found in the proportion of prey items according to season, sex and size class. M. azevia had the largest diet spectrum. Ages were determined from sagittal otoliths. The von Bertalanffy growth equation coefficients differed between sexes. The asymptotic length $L_{\infty}$ of females was higher than that of males, except in $C$. linguatula. The lowest growth coefficient was obtained for $P$. flesus ( $k=0.11$ for males and $k=0.10$ for females) and M. azevia showed the highest growth coefficient estimates ( $k=0.40$ for females and $k=0.30$ for males). The highest proportion of individuals at spawning stage was recorded in winter for L. boscii, P. flesus and M. azevia, and in autumn for C. linguatula.
\end{abstract}

Keywords: flatfish, diet, growth, otoliths, reproduction, Portuguese coast.

RESUMEN:DIETA,CRECIMIENTOY REPRODUCCIÓNDECUATROESPECIESDEPECESPLANOSENLACOSTA PORTUGUESA.-Cuatroespecies de peces planos fueron capturadas desde enero de 2003 hasta junio de 2005 por embarcaciones comerciales operando con redes de enmalle y arrastre de fondo, a lo largo de la costa portuguesa, con objeto de examinar los hábitos alimenticios, la edad, el crecimiento y el ciclo sexual. Citharus linguatula (Linnaeus, 1758), Lepidorhombus boscii (Risso, 1810) y Microchirus azevia (de Brito Capello, 1867), se alimentaron sobre todo de crustáceos. La dieta de Platichthys flesus (Linnaeus, 1758) estuvo compuesta principalmente por equinodermos y crustáceos. La mayor actividad alimenticia se observó en la primavera y el verano. Las hembras y los individuos más pequeños presentaron valores de índices de vacuidad más bajos. Para todas las especies se encontraron diferencias significativas en la proporción de ítems alimenticios según la estación, el sexo y la talla. M. azevia presentó el espectro más amplio de dieta. Las edades fueron determinadas a partir de los otolitos sagittae. Los coeficientes de la ecuación de crecimiento de von Bertalanffy fueron diferentes para los dos sexos. La talla asintótica $\mathrm{L}_{\infty}$ de las hembras fue mayor que la de los machos, excepto para $C$. linguatula. El coeficiente de crecimiento más bajo se observó para $P$. flesus ( $k=0.11$ para los machos y $k=0.10$ para las hembras), M. azevia presentó el mayor coeficiente de crecimiento ( $k=0.40$ para hembras y $k=0.30$ para machos). La mayor proporción de individuos maduros en L. boscii, P. flesus y M. azevia se observó en invierno y en C. linguatula en otoño.

Palabras clave: peces planos, dieta, crecimiento, otolitos, reproducción, costa portuguesa.

\section{INTRODUCTION}

A large number of flatfish species occur on the Portuguese coast (e.g. Nielsen, 1986a,b,c,d; Quéro et al., 1986a,b; Cabral, 2000a). This species richness is usually higher than that found in Northern Europe and similar to that found in the Mediterranean, since many flatfish species are at their southern or northern distribution limits along the Portuguese coast (e.g. Quéro et al., 1986a; Desoutter, 1997). The zoogeographic importance of this latitudinal area, representing the transition between northeastern Atlantic 
warm-temperate and cold-temperate regions, has long been recognised (Ekman, 1953; Briggs, 1974).

The majority of flatfish occurring on the Portuguese coast have a high commercial value and are caught by fisheries as target or by-catch species. Flatfish catches represent $4 \%$ of all the fish biomass landed on the Portuguese coast. However, the importance of flatfish fisheries is considerably higher due to the high commercial value of flatfish species, which account for nearly $11 \%$ of the economical value of all landings. According to official data, flatfish landings increased from 1998 to 2005 (source: Direcção Gerald as Pescas e Aquicultura [DGPA]).

Knowledge on the ecology of some flatfish species-especially those that are considered fisheries by-catches-is scarce. Spotted flounder Citharus linguatula (Linnaeus, 1758), four-spotted megrim Lepidorhombus boscii (Risso, 1810), flounder Platichthys flesus (Linnaeus, 1758) and bastard sole Microchirus azevia (de Brito Capello, 1867) are very different flatfish species with distinct distribution areas. The spotted flounder is distributed in the eastern Atlantic and Mediterranean, inhabiting soft bottoms from the coastline to a depth of about 200 m (Nielsen, 1986a). Four-spotted megrim occurs in the northeast Atlantic from the British Isles south to Cape Bojador, and is also found in the Mediterranean. It is common on soft bottoms at depths down to $700-800 \mathrm{~m}$ (Nielsen, 1986b). Flounder is common around the coasts of northern Europe and the Mediterranean. This species occurs on soft bottoms from shallow water down to $50 \mathrm{~m}$, and can tolerate brackish or fresh water (Nielsen, 1986d). Bastard sole occurs from the southern range of the Iberian Peninsula to the western part of the Mediterranean Sea and off the African coast, southward to Senegal. It is common on mud and sand of the continental shelf, from the shore down to $250 \mathrm{~m}$ (Quéro et al., 1986a).

Diet, age and growth and reproduction of Citharus lingutula have been studied in the Mediterranean and on the Atlantic coast of Morocco (e.g. Belghyti et al., 1993; Redon et al., 1994; Vassilopoulou and Papaconstantinou, 1994; García-Rodríguez and Esteban, 2000). Studies on four-spotted megrim diet, age and growth and reproduction have been conducted in the western Europe and Mediterranean (e.g. Santos, 1994; Vassilopoulou and Ondrias, 1999; Landa et al., 2002; Vassilopoulou, 2006). Several authors have studied the diet, age and growth and reproduction of Platichthys flesus in northwestern Europe and in the Black Sea (e.g. Summers, 1979; Beaumont and Mann, 1984; Andersen et al., 2005; Çiloğlu, 2005). Age and growth and reproduction of Microchirus azevia have been studied on the south coast of Portugal, in the Mediterranean and in southern Morocco (e.g. Belaid and Marinaro, 1983; Marfin and Hajji, 1988; Andrade, 1998; Afonso-Dias et al., 2005).

Studies conducted on the Portuguese coast have shown that $P$. flesus feed mainly on crustaceans, polychaetes and molluscs (Vinagre et al., 2005). Santos (1994) determined for Lepidorhombus boscii a maximum total length of $398 \mathrm{~mm}$. Longevity of M. azevia was 8 years and a maximum total length of $327 \mathrm{~mm}$ (Andrade, 1998). L. boscii and M. azevia spawns from winter to spring (Santos, 1994; AfonsoDias et al., 2005).

Despite these studies, knowledge on these species is scarce and integrative and comparative studies are lacking. As the Portuguese coast is a transition between temperate and subtropical waters of the northeastern Atlantic coasts, studies conducted in this area may provide important information for determining these trends. Therefore, the aim of the present work was to study the diet, age and growth and reproduction of four-spotted megrim, bastard sole, spottedflounder and flounder off the Portuguese coast.

\section{MATERIALS AND METHODS}

\section{Sampling surveys and samples processing}

Samples were collected bimonthly between January 2003 and June 2005 from commercial fishing vessels operating with gill nets and bottom trawls along the Portuguese coast. The whole Portuguese coast was sampled regularly throughout the year (a minimum of 40 individuals were obtained per sampling time and area).

Fish were identified, measured (total length to nearest $1 \mathrm{~mm}$ ) and weighed (total and eviscerated wet weight with $0.01 \mathrm{~g}$ precision). Stomachs and gonads were removed and frozen $\left(-20^{\circ} \mathrm{C}\right)$ for further analysis. Saggital otoliths were removed, cleaned and kept dry for later age determination.

\section{Diet}

The stomach contents of 344 individuals of $C$. linguatula (149-293 mm), 317 individuals of L. boscii (149-346 mm), 325 individuals of $P$. flesus (150- 
$430 \mathrm{~mm}$ ) and 314 individuals of M. azevia (149-313 $\mathrm{mm})$ were analysed. Each prey item was identified to the lowest taxonomic level possible, counted and weighed (wet weight to $0.001 \mathrm{~g}$ ). The relative importance of each prey item in the diet was expressed as a percent of numerical abundance (NI - numerical index), occurrence of food items in stomachs (OI occurrence index) and weight (GI - gravimetrical index) (Hyslop, 1980). Feeding activity was evaluated by the vacuity index (VI) defined as the percent of empty stomachs (Hyslop, 1980).

Correspondence analyses (CA) were run to evaluate diet variation with season, sex and fish length according to each of the three index values. Prey items were grouped in a broader taxonomic level and four seasons, and two size classes (size class 1: $<250 \mathrm{~mm}$ and size class $2: \geq 250 \mathrm{~mm}$ total length) were created. These analyses were performed using CANOCO version 4.5 (ter Braak and Smilauer, 2002).

Diet differences between seasons, sexes and fish size were evaluated using $\chi^{2}$ tests (Zar, 1984) and with a 0.05 significance level.

Prey diversity was determined for each season, sex and size class using the Shannon-Wiener diversity index H' (Shannon and Weaver, 1949), expressed as

$$
\mathrm{H}^{\prime}=-\sum_{\mathrm{i}=1}^{s} \mathrm{P}_{\mathrm{i}} \ln \mathrm{P}_{\mathrm{i}},
$$

where $P_{i}$ is the numerical proportion of the $i$ th prey category in the diet and $S$ is the total number of different prey categories consumed by the predator. This index corresponds to the dietary breadth (Marshall and Elliott, 1997).

\section{Age and growth}

Age was evaluated based on otolith readings. For each specimen, two counts of otolith annuli were made under a dissecting microscope. Whenever the two readings of the same otolith resulted in different age estimates, the data were not considered for further analysis. A total of 321 individuals (216 females and 105 males) of spotted flounder, 302 individuals (199 females and 103 males) of four-spotted megrim, 314 individuals (209 females and 105 males) of flounder and 292 individuals (147 females and 145 males) of bastard sole were used for age determination.

Estimates of theoretical growth in length were obtained by fitting length-at-age data to the von Bertalanffy growth equation:

$$
L_{t}=L_{\infty}\left(1-e^{-k\left(t-t_{0}\right)}\right),
$$

where $L_{t}$ is the total length, $L_{\infty}$ is the asymptotic length, $k$ is the growth coefficient and $t_{0}$ is the theoretical age at zero length. The growth parameters of this model were estimated iteratively using the least squares method in Statistica software. This analysis was performed separately for males and females.

\section{Reproduction}

Gonads were observed macroscopically and a maturation stage was assigned to each individual, according to the scale: I, immature; II, development; III, spawning; and IV, post-spawning (Cabral, 1998). For each season, the percentage of fish in stages I, II, III and IV was determined.

The gonadosomatic index (GSI) was also determined for each sex and season. The GSI was expressed as the percentage of the weight of gonads in relation to eviscerated weight of fish. Age and length at first maturity were determined.

\section{RESULTS}

\section{Diet}

C. linguatula fed mainly on mysids and fishes, L. boscii mainly on decapods and fishes, M. azevia mainly on polychaetes and decapods, and P. flesus mainly on echinoderms (particularly Holothuroida), bivalves and crustaceans (amphipods and decapods) (Table 1).

Vacuity index was higher for spotted flounder (34\%) than for four-spotted flounder (19\%), flounder (26\%) and bastard sole (29\%). The lowest values of vacuity occurred in summer, particularly for females and for the smallest fishes (Table 2).

The correspondence analysis (CA) based on the three indices considered as averaged per season, sex and size class explained $c a .30 \%$ of the variance in the first two axes $(29.8 \%, 37.8 \%$ and $31.5 \%$, respectively for NI, OI and GI). The three ordination diagrams (NI, OI and GI) were similar and the four species were well discriminated, so we presented only the best diagram: the numerical index diagram (Fig. 1).

In the ordination diagram obtained for numerical data it can be seen that $C$. linguatula was mostly associated with Mysida and fishes. The females' diet 
TABLE 1. - Numerical (NI), occurrence (OI) and gravimetric (GI) index values of prey items identified in stomachs of C. linguatula, L. boscii, $P$. flesus and M. azevia off the Portuguese coast.

\begin{tabular}{|c|c|c|c|c|c|c|c|c|c|c|c|c|}
\hline \multirow{2}{*}{$\begin{array}{l}\text { Species } \\
\text { Index }\end{array}$} & \multicolumn{3}{|c|}{ C. linguatula } & \multicolumn{3}{|c|}{ L. boscii } & \multicolumn{3}{|c|}{ P. flesus } & \multicolumn{3}{|c|}{ M. azevia } \\
\hline & NI & OI & GI & NI & OI & GI & NI & $\mathrm{OI}$ & GI & NI & OI & GI \\
\hline Foraminifera & & & & 63.7 & 0.8 & $<0.1$ & & & & 2.6 & 1.1 & $<0.1$ \\
\hline Bivalvia & $<0.1$ & 0.2 & $<0.1$ & & & & 17.8 & 23.0 & 26.3 & 9.0 & 4.3 & 3.6 \\
\hline Pecten spp. & & & & & & & & & 40 & & & \\
\hline Bivalvia n.i. & $<0.1$ & 0.2 & $<0.1$ & & & & $\begin{array}{l}2.6 \\
15.2\end{array}$ & 20.3 & $\begin{array}{c}4.0 \\
22.3\end{array}$ & 6.9 & 32 & 2.5 \\
\hline Antalis entalis & & & & & & & & & & 1.3 & 1.1 & 0.5 \\
\hline Gastropoda & $<0.1$ & 0.2 & $<0.1$ & 0.1 & 0.7 & $<0.1$ & & & & 7.3 & 3.2 & 2.4 \\
\hline $\begin{array}{l}\text { Hydrobia ulvae } \\
\text { Scaphander }\end{array}$ & & & & & & & & & & 1.3 & 0.5 & $<0.1$ \\
\hline Gastropoda n.i. & $<0.1$ & 0.2 & $<0.1$ & & & & & & & 1.7 & 1.6 & 1.1 \\
\hline Cephalopoda & 4.2 & 11.2 & 32.9 & 0.1 & 0.7 & 10.0 & & & & & & \\
\hline Sepia officinalis & $<0.1$ & 0.2 & 0.2 & & & & & & & & & \\
\hline Loliginidae & 1.5 & 4.2 & 27.4 & & & & & & & & & \\
\hline Alloteuthis spp. & 0.7 & 2.1 & 20.7 & & & & & & & & & \\
\hline Loligo vulgaris & $<0.1$ & 0.2 & 0.6 & & & & & & & & & \\
\hline Loliginidae n.i. & 0.7 & 1.9 & 6.1 & & & & & & & & & \\
\hline Octopodidae & 0.1 & 0.3 & 0.6 & & & & & & & & & \\
\hline Cephalopoda n.i. & 2.5 & 6.5 & 4.7 & & & & & & & & & \\
\hline $\begin{array}{l}\text { Polychaeta } \\
\text { Aphrodita aculeata }\end{array}$ & & & & 0.7 & 4.3 & 1.9 & 8.1 & 25.1 & 36.5 & $\begin{array}{c}30.9 \\
5.6\end{array}$ & $\begin{array}{c}33.4 \\
6.9\end{array}$ & $\begin{array}{l}52.6 \\
5.9\end{array}$ \\
\hline Polychaeta n.i. & & & & & & & 8.1 & 25.1 & 36.5 & 25.3 & 26.5 & 46.7 \\
\hline Crustacea & 80.9 & 52.0 & 20.2 & 33.1 & 82.7 & 64.7 & 18.2 & 25.7 & 6.3 & 36.5 & 42.8 & 31.2 \\
\hline $\begin{array}{l}\text { Balanus spp. } \\
\text { Squilla mantis }\end{array}$ & & & & 0.2 & 1.4 & 2.1 & 0.2 & 0.5 & $<0.1$ & & & \\
\hline Decapoda & 5.7 & 14.3 & 9.2 & 22.8 & 34.5 & 42.8 & 5.5 & 15.0 & 5.3 & 11.6 & 12.1 & 11.5 \\
\hline Paguridae & & & & & & & & & & 4.3 & 4.2 & 6.0 \\
\hline Brachyura & $<0.1$ & 0.1 & $<0.1$ & 1.8 & 7.9 & 9.8 & 5.4 & 14.4 & 5.0 & 6.0 & 6.3 & 3.9 \\
\hline Caridea & 3.9 & 9.5 & 6.6 & 21.0 & 26.6 & 33.0 & 0.2 & 0.5 & 0.3 & 0.9 & 1.1 & 1.5 \\
\hline Crangonidae & 0.9 & 2.2 & 0.8 & 0.4 & 2.2 & 0.8 & & & & & & \\
\hline Crangon crangon & 0.1 & 0.3 & 0.2 & 0.4 & 2.2 & 0.8 & & & & & & \\
\hline Philocheras spp. & 0.6 & 0.8 & 0.5 & & & & & & & & & \\
\hline Philocheras sculptus & $<0.1$ & 0.4 & $<0.1$ & & & & & & & & & \\
\hline Crangonidae n.i. & 0.1 & 0.7 & 0.1 & & & & & & & & & \\
\hline Alpheus glaber & 0.7 & 2.1 & 3.7 & & & & & & & & & \\
\hline Palaemonidae & 0.8 & 3.3 & 1.2 & & & & & & & & & \\
\hline Palaemon longirostris & $<0.1$ & 0.3 & 0.3 & & & & & & & & & \\
\hline Palaemonetes varians & $<0.1$ & 0.3 & 0.2 & & & & & & & & & \\
\hline Processa spp. & 0.5 & 1.5 & 0.4 & & & & & & & & & \\
\hline Palaenomidae n.i. & $<0.1$ & 1.2 & 0.3 & & & & & & & & & \\
\hline Caridea n.i. & 1.4 & 4.2 & 2.1 & 20.7 & 24.5 & 32.2 & & & & & & \\
\hline Decapoda n.i. & 1.8 & 4.5 & 2.6 & & & & & & & 0.4 & 0.5 & $<0.1$ \\
\hline Euphausiacea & 1.0 & 0.3 & 0.2 & & & & & & & & & \\
\hline Mysida & 63.6 & 22.5 & 4.8 & 2.2 & 13.7 & 5.3 & 0.7 & 2.1 & $<0.1$ & & & \\
\hline Leptomysis spp. & 26.4 & 6.9 & 1.6 & & & & & & & & & \\
\hline Mysida n.i. & 37.2 & 15.6 & 3.2 & & & & 0.7 & 2.1 & $<0.1$ & & & \\
\hline Isopoda & 0.3 & 0.8 & $<0.1$ & 3.8 & 9.4 & 9.6 & 0.5 & 1.6 & 0.1 & & & \\
\hline Eurydice spp. & 0.1 & 0.2 & $<0.1$ & & & & & & & & & \\
\hline Limnoria spp. & $<0.1$ & 0.2 & $<0.1$ & & & & & & & & & \\
\hline Isopoda n.i. & 0.2 & 0.5 & $<0.1$ & & & & 0.5 & 1.6 & 0.1 & & & \\
\hline Amphipoda & $<0.1$ & 0.2 & $<0.1$ & 0.1 & 0.7 & $<0.1$ & 9.9 & 2.1 & 0.1 & 9.9 & 12.2 & 6.4 \\
\hline Crustacea n.i. & 10.4 & 13.8 & 4.8 & 3.9 & 23.0 & 4.8 & 1.4 & 4.3 & 0.8 & 15.0 & 18.5 & 13.3 \\
\hline Echinodermata & $<0.1$ & 0.2 & $<0.1$ & 0.2 & 1.4 & $<0.1$ & 51.9 & 15.0 & 20.7 & 9.4 & 10.6 & 2.2 \\
\hline Crinoidea & & & & & & & 0.3 & 1.1 & $<0.1$ & & & \\
\hline Ophiuroidea & & & & 0.1 & 0.7 & $<0.1$ & & & & 3.0 & 3.7 & 1.0 \\
\hline Holothuroidea & & & & & & & 51.4 & 13.4 & 20.7 & & & \\
\hline Echinoidea & $<0.1$ & 0.2 & $<0.1$ & & & & & & & & & \\
\hline Echinodermata n.i. & & & & 0.1 & 0.7 & $<0.1$ & 0.2 & 0.5 & $<0.1$ & 6.4 & 6.9 & 1.2 \\
\hline Actinopterygii & 12.5 & 29.8 & 44.5 & 2.1 & 9.4 & 23.3 & 1.0 & 2.1 & 3.7 & & & \\
\hline Pleuronectiformes & 0.3 & 0.5 & 2.9 & & & & & & & & & \\
\hline Arnoglossus spp. & $<0.1$ & 0.2 & 0.6 & & & & & & & & & \\
\hline Pleuronectiformes n.i. & 0.3 & 0.3 & 2.3 & & & & & & & & & \\
\hline Ammoditidae & & & & & & & 0.3 & 0.5 & 2.4 & & & \\
\hline Callionymus spp. & $<0.1$ & 0.2 & 0.1 & & & & & & & & & \\
\hline Callionymus reticulatus & $<0.1$ & 0.2 & 1.8 & & & & & & & & & \\
\hline Trachinidae & $<0.1$ & 0.2 & 0.2 & & & & & & & & & \\
\hline Gobiidae & 0.2 & 0.4 & 1.8 & & & & & & & & & \\
\hline Gobius niger & 0.1 & 0.2 & 1.0 & & & & & & & & & \\
\hline Pomatoschistus microps & $<0.1$ & 0.1 & 0.1 & & & & & & & & & \\
\hline Gobiidae n.i. & $<0.1$ & 0.1 & 0.7 & & & & & & & & & \\
\hline Trachurus trachurus & 0.1 & 0.2 & 5.5 & & & & & & & & & \\
\hline Lepidotrigla cavillone & $<0.1$ & 0.2 & 0.5 & & & & & & & & & \\
\hline Merluccius merluccius & $<0.1$ & 0.2 & 0.3 & & & & & & & & & \\
\hline Actinopterygii n.i. & 11.6 & 27.7 & 31.4 & & & & 0.7 & 1.6 & 1.3 & & & \\
\hline Unidentified & 2.1 & 6.4 & 2.1 & & & & 2.9 & 9.1 & 6.5 & 3.0 & 3.7 & 7.8 \\
\hline
\end{tabular}


TABLE 2. - Vacuity index (VI) for each season (W, winter; Sp, spring; S, summer; A, autumn), sex (F, females; M, males) and size class (I, size class I; II, size class II) for C. linguatula, L. boscii, P. flesus and M. azevia.

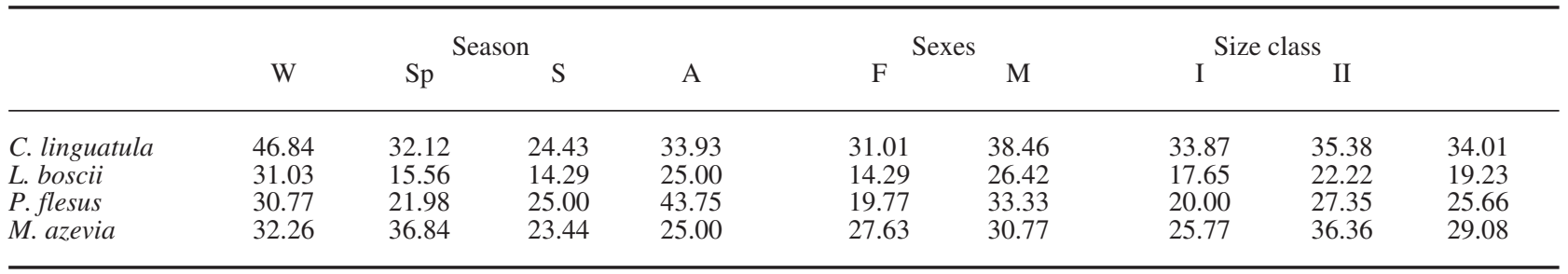

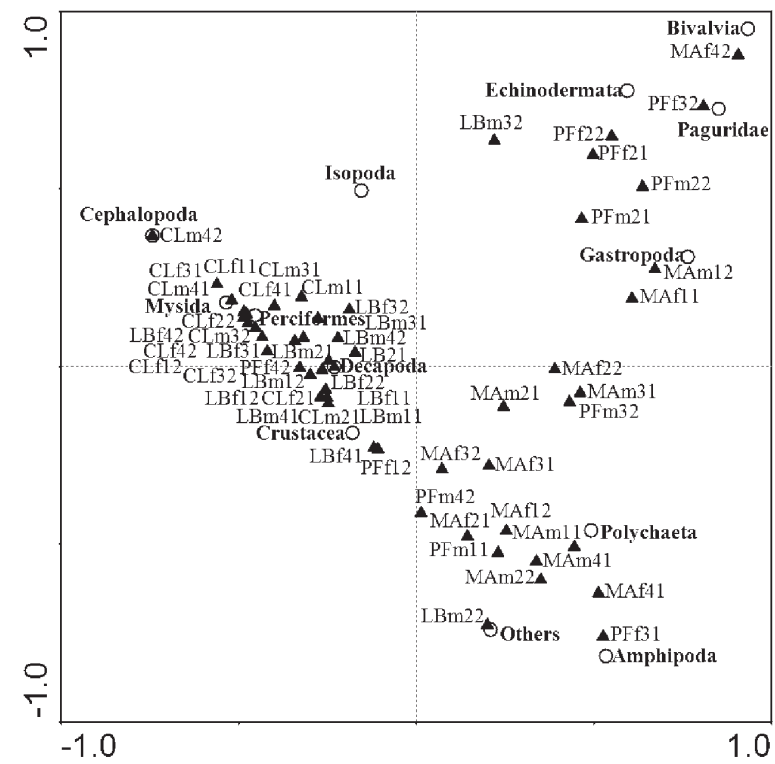

FIG. 1. - Ordination diagrams of the correspondence analyses performed on numerical index values of prey found in guts of $C$ linguatula (CL), L. boscii (LB), P. flesus (PF) and M. azevia (MA) (f, females; m, males; 1 , winter; 2, spring; 3, summer; 4, autumn; 1 , size class I; 2 , size class II).

in spring, summer and winter was composed of decapods. Small males were associated with crustaceans in spring, and the largest males were associated with cephalopods in autumn. The diet of $L$. boscii was composed mainly of decapods and fishes. Crustaceans were associated with small females in autumn. $P$. flesus was chiefly associated with echinoderms in the spring. Amphipods were associated with small females in summer. The largest females' diet was associated with pagurids in summer. The diet of $M$. azevia was composed mainly of polychaetes and in winter it was associated with gastropods. Bivalves were associated with females. In autumn the diet of small females was composed of amphipods.

C. linguatula, L. boscii, P. flesus and M. azevia showed significant differences in their diets between seasons $\quad\left(\chi^{2}=414.0, \quad\right.$ d.f. $=33, \quad \mathrm{P}<0.05 ; \quad \chi^{2}=384.8$, d.f.=33, $\mathrm{P}<0.05 ; \chi^{2}=523.6$, d.f. $=33, \mathrm{P}<0.05$ and $\chi^{2}=60.0$, d.f. $=11, \mathrm{P}<0.05$, respectively).
Significant differences in the diet were observed between sexes in $C$. linguatula, $L$. boscii and P. flesus $\left(\chi^{2}=31.7\right.$, d.f. $=11, \mathrm{P}<0.05 ; \chi^{2}=461.6$, d.f. $=11, \mathrm{P}<0.05$ and $\chi^{2}=115.9$, d.f. $=11, \mathrm{P}<0.05$, respectively).

The diet of individuals of the two size classes also differed significantly in spotted flounder, fourspotted megrim and flounder $\left(\chi^{2}=294.5\right.$, d.f. $=11$, $\mathrm{P}<0.05 ; \chi^{2}=558.4$, d.f. $=11, \mathrm{P}<0.05$ and $\chi^{2}=133.7$, d.f. $=11, \mathrm{P}<0.05$, respectively).

$M$. azevia and $C$. linguatula showed the highest values of dietary diversity, obtained for the winter $\left(H^{\prime}=2.24\right)$ and spring $\left(H^{\prime}=2.26\right)$, respectively. For the majority of the species, males $(C$. linguatula: $\mathrm{H}^{\prime}=1.93 ;$ P. flesus: $\mathrm{H}^{\prime}=2.01 ;$ M. azevia: $\mathrm{H}^{\prime}=2.40$ ) showed a higher dietary breath than females $(C$. linguatula: $\mathrm{H}^{\prime}=1.81 ;$ P. flesus: $\mathrm{H}^{\prime}=1.43 ;$ M. azevia: $\left.\mathrm{H}^{\prime}=2.39\right)$. However, L. boscii showed an opposite trend, the females' diet $\left(\mathrm{H}^{\prime}=1.70\right)$ being more diverse than that of males $\left(H^{\prime}=0.66\right)$. For $C$. linguatula and $M$. azevia the dietary diversity increased with size (size class I: $\mathrm{H}^{\prime}=1.81$; size class II: $\mathrm{H}^{\prime}=2.12$ and size class I: $\mathrm{H}^{\prime}=2.30$; size class II: $\mathrm{H}^{\prime}=2.49$, respectively). On the other hand, L. boscii and P. flesus showed the opposite trend: dietary diversity was higher for smaller-size individuals (size class I: $\mathrm{H}^{\prime}=1.43$; size class II: $H^{\prime}=0.61$ and size class I: $H^{\prime}=1.52$; size class II: $\mathrm{H}^{\prime}=1.51$, respectively).

\section{Age and growth}

The total length of fishes analysed varied between 149 and $275 \mathrm{~mm}$ for spotted-flounder, between 149 and $346 \mathrm{~mm}$ for four-spotted megrim, between 200 and $430 \mathrm{~mm}$ for flounder, and between 149 and 275 $\mathrm{mm}$ for bastard sole. The age ranged from 1 to 7 years in spotted flounder, from 2 to 9 years in four-spotted megrim, from 2 and 14 years in flounder, and from 2 and 7 years in bastard sole.

All species showed a differential growth according to sex. For the majority of the species (L. boscii, $P$. flesus and M. azevia) females attained higher lengths than males, except for $C$. linguatula (Figs. 2 

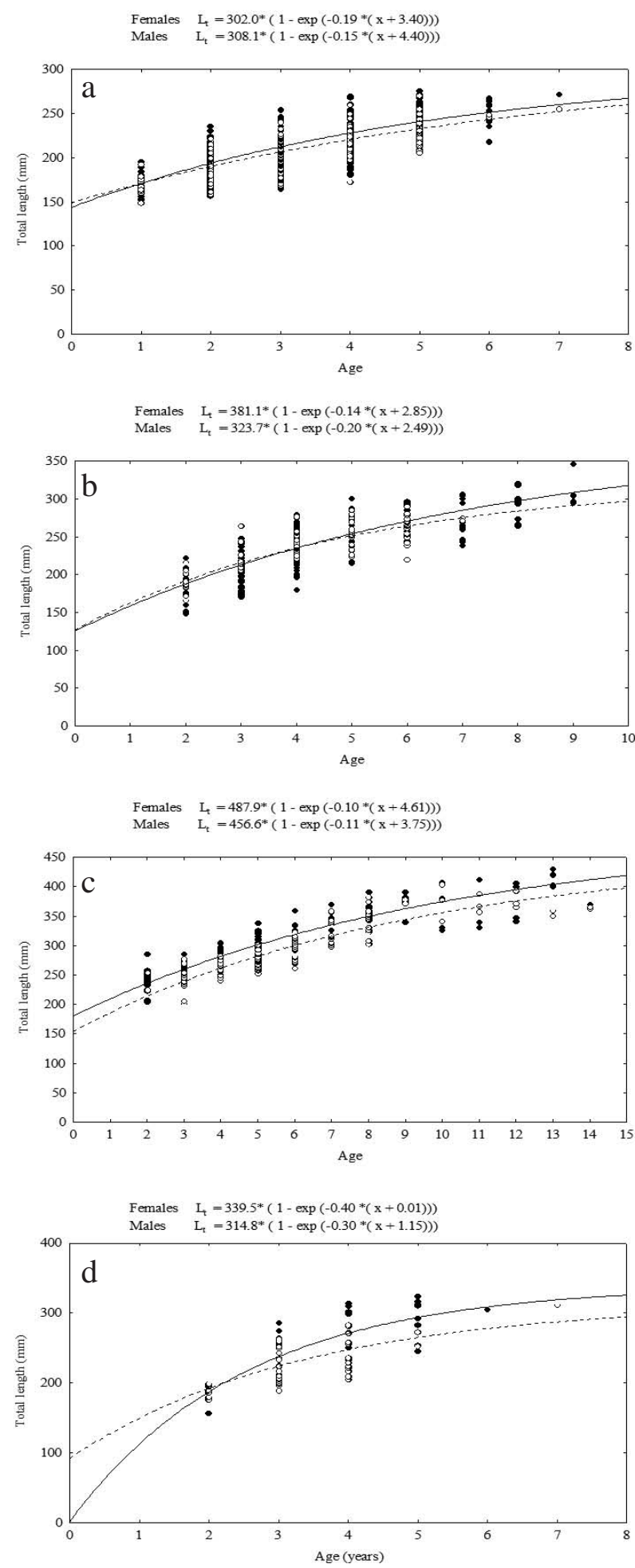

FIG. 2. - von Bertalanffy growth curves fitted to length-at-age data of C. linguatula (a), L. boscii (b), P. flesus (c), and M. azevia (d) (females, black circles and solid lines; males, empty circles and dashed lines)

$a, b, c, d)$. The estimated asymptotic lengths for spotted flounder were higher for males than for females ( $L_{\infty}=308.1 \mathrm{~mm}$ and $L_{\infty}=302.0 \mathrm{~mm}$, respectively).

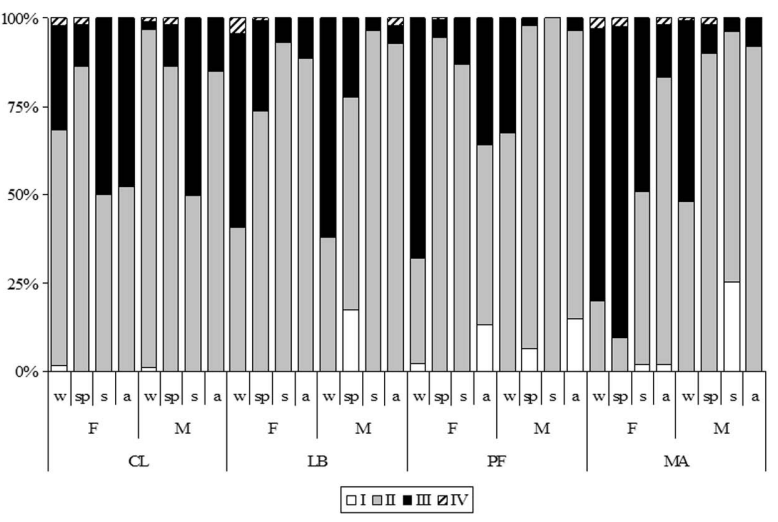

FIG. 3. - Percentage of individual of C. linguatula (CL), L. boscii (LB), P. flesus (PF) and M. azevia (MA) in each maturation stage (I, Immature; II, Development; III, Spawning; IV, Post-spawning), according to season (w, winter; sp, spring; s, summer; a, autumn) and to sex (F, females; M, males).

For the other species, an opposite trend was noticed: four-spotted megrim females, $L_{\infty}=381.1 \mathrm{~mm}$ and males, $L_{\infty}=323.7 \mathrm{~mm}$; flounder females, $L_{\infty}=487.9$ $\mathrm{mm}$ and males, $L_{\infty}=456.6 \mathrm{~mm}$; and bastard sole females, $L_{\infty}=339.5 \mathrm{~mm}$ and males, $L_{\infty}=314.8 \mathrm{~mm}$. The growth coefficient of spotted flounder (females, $k=0.19$; males, $k=0.15$ ) and bastard sole (females, $k=0.40$ and males, $k=0.30$ ) were higher for females than males, while for four-spotted megrim estimated $k$ for males was higher than that of females (females, $k=0.14$ and males, $k=0.20$ ). For flounder, growth coefficient estimates were similar for both sexes (females, $k=0.10$ and males, $k=0.11$ ). The $t_{0}$ estimates for spotted flounder were -3.40 for females and -4.40 for males; those for four-spotted megrim were -2.85 for females, and -2.49 for males; those for flounder were -4.61 for females and -3.75 for males; and those for bastard sole were -0.01 for females and -1.15 for males.

\section{Reproduction}

For all the species studied, the percentage of individuals in each maturation stage per season was in agreement with results relative to GSI values (Figs. 3 and 4).

The highest GSI values were obtained in winter for L. boscii, P. flesus and M. azevia, corresponding to the period with the highest percentage of individuals in stage III (spawning). The GSI values obtained for $C$. linguatula were high in autumn.

L. boscii and C. linguatula were the species for which the sexual maturation occurred in individuals with the lowest age and size (2 years for both, and $182 \mathrm{~mm}$ and $190 \mathrm{~mm}$, respectively). Except for $P$. 

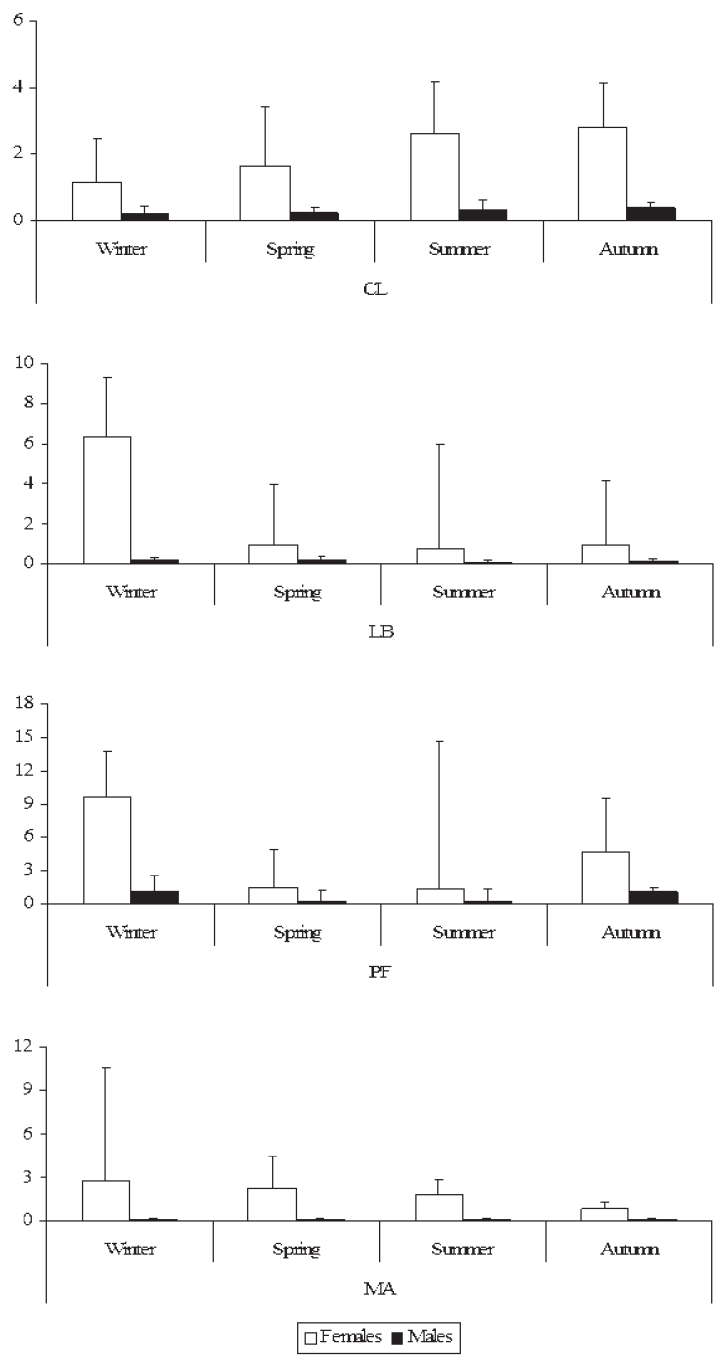

FIG. 4. - Gonadosomatic index mean values per season determined for each sex (standard deviation is represented above bars).

flesus (females, 3 years and males, 2 years), all the other species had the same age at first maturity for both sexes. M. azevia attained the first sexual maturity at 3 years of age.

\section{DISCUSSION}

\section{Diet}

The present study showed that Citharus linguatula fed mainly on mysids and fishes, Lepidorhombus boscii mainly on decapods and fishes, Microchirus azevia mainly on polychaetes and decapods, and Platichthys flesus mainly on echinoderms, bivalves and crustaceans. Studies conducted in western Europe (e.g. de Groot, 1971; Serrano et al., 2003;
Vinagre et al., 2005), in the Mediterranean (e.g. Morte et al., 1999; de Juan et al., 2007) and on the Atlantic coast of Morocco (Belghyti et al., 1993) have reported similar results to those obtained herein (Table 3). The present study was the first approach to the feeding ecology of M. azevia, and our results revealed that the diet of this species was similar to that of other Soleidae, the main prey being crustaceans, polychaetes and molluscs (e.g. Cabral, 2000b; Darnaude et al., 2001).

The relative importance of each prey differed greatly according to species. Several authors have reported differences in the feeding behaviour between Pleuronectiformes families (de Groot, 1971; Braber and de Groot, 1973; Holmes and Gibson, 1983). Diet composition depends mainly on prey detection mode and gut morphology. Citharidae, Scophthalmidae and Pleuronectidae are visual predators, responding primarily to moving prey, while Soleidae are mainly night feeders consuming less mobile or sedentary prey (de Groot, 1971; Braber and de Groot, 1973). The present study showed that feeding activity was higher in summer, the females showed lower vacuity values than males and the largest individuals had lower feeding activity than the smallest ones. This feeding behaviour is consistent with the findings of several authors (Belghyti et al., 1993; Vassilopoulou, 2006; de Juan et al., 2007). However, some authors (Redon et al., 1994; Morte et al., 1999; de Juan et $a l ., 2007)$ have reported that the vacuity index was highest in spring-summer. The variations in feeding activity result from the interactions of many factors, such as prey availability and reproductive process. In temperate areas, the highest productivity is recorded in spring and summer, which may increase the prey availability. Also, females have higher energetic needs for growth and reproduction, which could explain the lower vacuity values (Pitt, 1973; Lozán, 1992). Smaller fish have higher growth rates during the first years of life, which is usually related to a more intense feeding activity during this period to maximise growth (Vassilopoulou and Ondrias, 1999).

The diet of the four flatfish species analysed in this study showed seasonal, ontogenic and sexual variations, which were concordant with previous studies (e.g. Redon et al., 1994; Andersen et al., 2005; Vassilopoulou, 2006). These variations could be related to changes in space and time of benthic prey (e.g. Matallanas, 1982; Wootton, 1998). Several authors (e.g. Braber and de Groot, 1973; Gerking, 
TABLE 3. - Summary of main prey items, growth parameters and reproduction season for Citharus linguatula, Lepidorhombus boscii, Platichthys flesus and Microchirus azevia in different areas.

\begin{tabular}{|c|c|c|c|c|c|}
\hline Species & Main prey items & Growth parameters & Reproduction season & Area & Author \\
\hline \multirow[t]{6}{*}{ C. linguatula } & Mysids and fishes & $\begin{array}{l}\text { Females: } \mathrm{L}_{\infty}=302.0 \mathrm{~mm} ; \\
k=0.19 ; t=-3.40 \\
\text { Males: } \mathrm{L}_{\infty}=308.1 \mathrm{~mm} ; \\
k=0.15 ; t=-4.40\end{array}$ & autumn & Portugal & Present study \\
\hline & $\begin{array}{l}\text { Mysids, euphausiids, } \\
\text { prawns, cephalopods } \\
\text { and fishes }\end{array}$ & No data & No data & $\begin{array}{l}\text { Morocco } \\
\text { (Atlantic coast) }\end{array}$ & Belghyti et al., 1993 \\
\hline & $\begin{array}{l}\text { Mysids, decapods } \\
\text { and fishes }\end{array}$ & No data & No data & $\begin{array}{l}\text { Spain } \\
\text { (Mediterranean coast) }\end{array}$ & Redon et al., 1994 \\
\hline & No data & $\begin{aligned} \mathrm{L}_{\infty} & =253.4 \mathrm{~mm} ; k=0.25 \\
t & =1.68\end{aligned}$ & No data & Turkey (Aegean Sea) & $\begin{array}{l}\text { Türker Çakir et al., } \\
2005\end{array}$ \\
\hline & Crustaceans and fishes & No data & No data & $\begin{array}{l}\text { Spain } \\
\text { (Mediterranean coast) }\end{array}$ & de Juan et al., 2007 \\
\hline & No data & $\begin{array}{l}\text { Females: } \mathrm{L}_{\infty}=258.8 \mathrm{~mm} ; \\
k=0.26 ; t=-0.417 \\
\text { Males: } \mathrm{L}_{\infty}=229.4 \mathrm{~mm} ; \\
k=0.29 ; t=-0.457\end{array}$ & No data & Aegean Sea & $\begin{array}{l}\text { Vassilopoulou and } \\
\text { Papaconstantinou, } \\
1994\end{array}$ \\
\hline \multirow[t]{7}{*}{ L. boscii } & Decapods and fishes & $\begin{array}{l}\text { Females: } \mathrm{L}_{\infty}=381.1 \mathrm{~mm} ; \\
k=0.14 ; t=-2.85 \\
\text { Males: } \mathrm{L}_{\infty}=323.7 \mathrm{~mm} ; \\
k=0.20 ; t=-2.49\end{array}$ & winter & Portugal & Present study \\
\hline & No data & $\begin{array}{l}\text { Females: } \mathrm{L}_{\infty}=398.0 \mathrm{~mm} ; \\
k=0.16 ; t=-1.86 \\
\text { Males: } \mathrm{L}_{\infty}=348.0 \mathrm{~mm} ; \\
k=0.20 ; t=-1.44\end{array}$ & $\begin{array}{l}\text { winter and } \\
\text { spring }\end{array}$ & Portugal & Santos, 1994 \\
\hline & $\begin{array}{l}\text { Decapods, mysids, } \\
\text { amphipods and fishes }\end{array}$ & No data & No data & $\begin{array}{l}\text { Spain } \\
\text { (Mediterranean coast) }\end{array}$ & Morte et al., 1999 \\
\hline & No data & $\begin{array}{l}\text { Females: } \mathrm{L}_{\infty}=305.0 \mathrm{~mm} ; \\
k=0.18 ; t=-1.11 \\
\text { Males: } \mathrm{L}_{\infty}=255.3 \mathrm{~mm} ; \\
k=0.22 ; t=-1.08\end{array}$ & No data & Mediterranean waters & $\begin{array}{l}\text { Vassilopoulou and } \\
\text { Ondrias, } 1999\end{array}$ \\
\hline & No data & $\begin{array}{c}\mathrm{L}_{\infty}=343.9 \mathrm{~mm} ; k=0.27 \\
t=-1.99\end{array}$ & No data & Ireland & Robson et al., 2000 \\
\hline & No data & $\begin{array}{l}\text { Females: } \mathrm{L}_{\infty}=456.0 \mathrm{~mm} ; \\
k=0.17 ; t=0.07 \\
\text { Males: } \mathrm{L}_{\infty}=399.0 \mathrm{~mm} ; \\
k=0.17 ; t=-0.37\end{array}$ & No data & Northeast Atlantic & Landa et al., 2002 \\
\hline & $\begin{array}{l}\text { Decapods, mysids, } \\
\text { isopods, amphipods } \\
\text { and fishes }\end{array}$ & No data & No data & Mediterranean waters & Vassilopoulou, 2006 \\
\hline \multirow[t]{11}{*}{ P. flesus } & $\begin{array}{l}\text { Echinoderms, bivalves, } \\
\text { amphipods and } \\
\text { decapods. }\end{array}$ & $\begin{array}{l}\text { Females: } \mathrm{L}_{\infty}=487.9 \mathrm{~mm} ; \\
k=0.10 ; t=-4.61 \\
\text { Males: } \mathrm{L}_{\infty}=456.6 \mathrm{~mm} ; \\
k=0.11 ; t=-3.75\end{array}$ & winter & Portugal & Present study \\
\hline & No data & No data & spring & Poland & Cieglewicz, 1962 \\
\hline & No data & No data & spring & Scotland & Rae, 1971 \\
\hline & $\begin{array}{c}\text { Crustaceans, polychaetes, } \\
\text { bivalves and gastropods }\end{array}$ & No data & No data & Scotland & Summers, 1979 \\
\hline & No data & $\begin{array}{l}\text { Females: } \mathrm{L}_{\infty}=485.0 \mathrm{~mm} ; \\
k=0.53 ; t=0.67 \\
\text { Males: } \mathrm{L}_{\infty}=351.8 \mathrm{~mm} ; \\
k=0.67 ; t=0.31\end{array}$ & No data & France (Atlantic coast) & Deniel, 1981 \\
\hline & $\begin{array}{l}\text { Insects, molluscs and } \\
\text { crustaceans }\end{array}$ & No data & No data & England & $\begin{array}{l}\text { Beaumont and Mann, } \\
1984\end{array}$ \\
\hline & & & $\begin{array}{l}\text { winter } \\
\text { winter }\end{array}$ & $\begin{array}{l}\text { Portugal } \\
\text { France (Atlantic coast) }\end{array}$ & $\begin{array}{l}\text { Sobral, } 2007 \\
\text { Masson. } 1988\end{array}$ \\
\hline & & $\begin{array}{l}\text { Females: } \mathrm{L}_{\infty}=386.9 \mathrm{~mm} ; \\
k=0.70 ; t=-0.02 \\
\text { Males: } \mathrm{L}_{\infty}=304.5 \mathrm{~mm} ; \\
k=0.99 ; t=-0.04\end{array}$ & & & Vianet et al., 1989 \\
\hline & $\begin{array}{l}\text { Copepods, polychaetes, } \\
\text { oligochaetes, amphipods, } \\
\text { isopods and fishes }\end{array}$ & No data & No data & Denmark & Andersen et al., 2005 \\
\hline & No data & $\begin{array}{l}\text { Females: } \mathrm{L}_{\infty}=412.4 \mathrm{~mm} ; \\
k=0.16 ; t=-3.24 \\
\text { Males: } \mathrm{L}_{\infty}=335.7 \mathrm{~mm} ; \\
k=0.18 ; t=-3.53\end{array}$ & $\begin{array}{l}\text { winter and } \\
\text { spring }\end{array}$ & Turkey (Black Sea) & Çiloğlu, 2005 \\
\hline & $\begin{array}{l}\text { Crustaceans and } \\
\text { polychaetes }\end{array}$ & No data & No data & Portugal & Vinagre et al., 2005 \\
\hline
\end{tabular}


TABLE 3 (cont.). - Summary of main prey items, growth parameters and reproduction season for Citharus linguatula, Lepidorhombus boscii, Platichthys flesus and Microchirus azevia in different areas.

\begin{tabular}{|c|c|c|c|c|c|}
\hline Species & Main prey items & Growth parameters & Reproduction season & Area & Author \\
\hline \multirow[t]{5}{*}{ M. azevia } & $\begin{array}{l}\text { Polychaetes and } \\
\text { decapods }\end{array}$ & $\begin{array}{l}\text { Females: } \mathrm{L}_{\infty}=339.5 \mathrm{~mm} \\
k=0.40 ; t=-0.01 \\
\text { Males: } \mathrm{L}_{\infty}=314.8 \mathrm{~mm} \\
k=0.30 ; t=-1.15\end{array}$ & winter & Portugal & Present study \\
\hline & No data & No data & spring & Algeria & $\begin{array}{l}\text { Belaid and Marinaro, } \\
1983\end{array}$ \\
\hline & No data & $\begin{array}{c}\mathrm{L}_{\infty}=479.9 \mathrm{~mm} ; k=016 \\
t=-0.56\end{array}$ & No data & Morocco & Marfi and Hajji, 1988 \\
\hline & No data & $\begin{array}{l}\text { Females: } \mathrm{L}_{\infty}=347.1 \mathrm{~mm} ; \\
k=0.28 ; t=-1.08 \\
\text { Males: } \mathrm{L}_{\infty}=336.7 \mathrm{~mm} \\
k=0.30 ; t=-1.07\end{array}$ & No data & Portugal & Andrade, 1998 \\
\hline & No data & No data & winter and spring & Portugal & Afonso-Dias et al., 2005 \\
\hline
\end{tabular}

1994; Platell and Potter, 1998) have shown that an increase in size of fish is associated with an increase in the consumption of larger prey, reflecting in some species a combination between increase in mouth size and improved ability to handle prey and to swim faster. This is in agreement with the optimum foraging theory (Gerking, 1994), according to which larger predators consume larger prey to maximise the energy gain relative to capture effort.

M. azevia showed a broader diet spectrum than the other three flatfish species, according to season, sex and size class. The diet breadth of $M$. azevia was higher in seasons when the feeding activity was lowest, which could correspond to a balance to compensate the decrease in prey availability during these seasons (Vassilopoulou, 2006).

\section{Age and growth}

The present study showed that the asymptotic length $\left(L_{\infty}\right)$ obtained for $C$. linguatula was higher than that obtained in studies conducted in the eastern Mediterranean (Vassilopoulou and Papaconstantinou, 1994; Türker Çakir et al., 2005). The opposite situation was observed for the growth coefficient $(k)$. The estimate of von Bertalanffy parameters obtained for $L$. boscii is in agreement with those estimated by several authors in different geographical locations (e.g. Santos, 1994; Vassilopoulou and Ondrias, 1999; Robson et al., 2000). The growth coefficient (k) was similar to those obtained in previous studies, except for Robson et al. (2000), who reported a higher growth coefficient. The values of asymptotic length for $P$. flesus obtained in this work were higher than those of earlier studies. This fact could be related to the smaller length of the fish in the studies conducted in the North Atlantic and the Mediterranean (Deniel, 1981; Vianet et al., 1989). The growth coefficient obtained in this study was smaller than those obtained in previous studies. Growth studies for $M$. azevia were scarce and all were conducted on the Portuguese coast. The estimate of von Bertalanffy parameters obtained in this work was similar to that of Andrade $(1990,1998)$ for the southern coast of Portugal (Table 3).

Growth can be influenced by many factors. Latitudinal variations in temperature induce variations in maintenance metabolism (Pauly, 1994a). The different growth patterns between sexes could be explained by the differences in metabolism between females and males, such as differences in oxygen consumption (Pauly, 1994b), differences in the level of surplus energy between reproduction and somatic growth (Rijnsdorp and Ibelings, 1989), and differential food ingestion (Lozán, 1992).

\section{Reproduction}

The analysis of seasonal variation of gonadal development and the GSI values suggests that the spawning period of L. boscii, P. flesus and M. azevia occurs in the winter, and that of $C$. linguatula occurs in the autumn. Studies on the reproduction of spotted flounder are scarce and report only length and age at first maturity. Vassilopoulou and Papaconstantinou (1994) and García-Rodriguez and Esteban (2000) suggested that age at first maturity was between the first and the third year of life, being earlier in males. The results obtained in the present study were consistent with those of previous studies, except for the length at first maturity, which was higher than that of earlier studies. The pattern of sexual devel- 
opment pointed out for M. azevia is consistent with the existing literature (Andrade, 1990; Afonso-Dias et al., 2005). The age at first maturity obtained in the present study was similar to that of earlier studies (Belaid and Marinaro, 1983; Andrade, 1990; Afonso-Dias et al., 2005). The results concerning the seasonal variation of gonadal development in the present work for $L$. boscii were similar to those of previous studies (Santos, 1994). The spawning season of $P$. flesus proposed by several authors outlines a latitudinal gradient, with later spawning at higher latitudes. Studies carried out in Northern Europe have shown that flounder spawns at the end of spring (e.g. Cieglewicz, 1962; Solemdal, 1967; Rae, 1971), while in northern French and Spanish coasts the spawning occurs mainly in the winter (e.g. Deniel, 1981; Masson, 1988). Similar results were shown in the previous studies conducted, whereas on the Portuguese coast the spawning occurs mainly in winter (Sobral, 2007). Our results were in agreement with earlier work (Table 3). The length at first maturity obtained in the present study was higher than those reported in previous studies (e.g. Masson, 1988; Kosior et al., 1996), which could be explained by the higher growth rates at lower latitudes.

Further studies on the bioecology of these species are needed in order to bring new insights into the population dynamics of these commercially important flatfish species.

\section{ACKNOWLEDGEMENTS}

This study was partially financed by the Fundação para a Ciência e a Tecnologia (FCT) through the grant awarded to C.M. Teixeira (Grant SFRH/ BD/19319/2004). This study was also co-funded by the European Union through the FEDER Fisheries Programme (MARE).

\section{REFERENCES}

Afonso-Dias, I., C. Reis and J.P. Andrade. - 2005. Reproductive aspects of Microchirus azevia (Risso, 1810) (Pisces: Soleidae) from the south coast of Portugal. Sci. Mar., 69(2): 275-283.

Andersen, B.S., J.D. Carl, P. Grønkjær and J.G. Støttrup. - 2005. Feeding ecology and growth of age 0 year Platichthys flesus (L.) in a vegetated and a bare sand habitat in a nutrient rich fjord. J. Fish Biol., 66: 531-552.

Andrade, J.P.A.S. - 1990. A importância da Ria Formosa no ciclo biológico de Solea senegalensis Kaup 1858, Solea vulgaris Quensel 1806, Solea lascaris (Risso, 1810) e Microchirus azevia (Capello, 1868). Ph.D. thesis, Univ. Algarve.

Andrade, J.P. - 1998. Age and growth of the bastard sole, Micro- chirus azevia (Capello, 1868) (Pisces, Soleidae) from the south coast of Portugal. Fish. Res., 34: 205-208.

Beaumont, W.R.C. and R.H.K. Mann. - 1984. The age, growth and diet of a freshwater population of the flounder, Platichthys flesus (L.), in the southern England. J. Fish Biol., 25: 617-623.

Belaid, B. and J.Y. Marinaro. - 1983. Biologie de la reproduction de Microchirus azevia (Capello) (Téléostéen soléidé). Rapp. Comm. Int. Mer Médit., 28(5): 59-60.

Belghyti, D., P. Aguesse and C. Gabrion. - 1993. Éthologie alimentaire de Citharus linguatula et Dicologoglossa cuneata sur les côtes atlantiques du Maroc. Vie Milieu, 43: 95-108.

Braber, L. and S.J. de Groot. - 1973. The food of five flatfish species (Pleuronectiformes) in the soutern Nort Sea. Neth. J. Sea Res., 6: 163-172.

Briggs, J.C. - 1974. Marine zoogeography. McGraw-Hill, London.

Cabral, H.M.R.N. - 1998. Utilização do estuário do Tejo como área de viveiro pelos linguados, Solea solea $(L ., 1758)$ e Solea senegalensis Kaup, 1858, e robalo, Dicentrarchus labrax (L., 1758). Ph.D. thesis, Univ. Lisboa.

Cabral, H.N. - 2000a. Distribution and abundance patterns of flatfishes in the Sado estuary, Portugal. Estuaries, 53: 351-358.

Cabral, H.N. - 2000b. Comparative feeding ecology of sympatric Solea solea and S. senegalensis, within the nursery areas of the Tagus estuary, Portugal. J. Fish Biol., 57: 1550-1562.

Cieglewicz, W. - 1962. The maturation of the flounder (Pleuronectes flesus) and composition of the shoal of the spawning flounder in the bay of Danzig. Arch. Hydrobiol. Ichtyol., 11: 8-13.

Çiloğlu, E. - 2005. Determination of the recruitment to stock and reproduction period for flounder (Platichthys flesus luscus Pallas, 1811) along the Trabzon-Rize Coast, Eastern Black Sea. Turk. J. Vet. Anim. Sci., 29: 43-48

Darnaude, A.M., M.L. Harmelin-Vivien and C. Salen-Picard. - 2001. Food partitioning among flatfish (Pisces: Pleuronectiformes) juveniles in a Mediterranean coastal shallow sandy area. J. Mar. Biol. Ass. U.K., 81: 119-127.

Desoutter, M. - 1997. Révision systématique des genres de la famille des Soleidae présents sur les côtes de l'Est-Atlantique et de la Méditerranée. Ph.D. thesis, Muséum National d'Histoire Naturelle, Paris.

de Groot, S.J. - 1971. On the interrelationships between morphology of the alimentary tract, food and feeding behaviour in flatfishes (Pisces: Pleuronectiformes). Neth. J. Sea Res., 5: 121-196.

de Juan, S., J.E. Cartes and M. Demestre - 2007. Effects of commercial trawling activities in the diet of the flat fish Citharus linguatula (Osteichthyes: Pleuronectiformes) and the starfish Astropecten irregularis (Echinodermata: Asteroidea). J. Exp. Mar. Biol. Ecol., 349: 152-169.

Deniel, C. - 1981. Les poissons plats (Téléostéens-Pleuronectiformes) en Baie de Douarnenez. Reproduction, croissance et migration des Bothidae, Scophthalmidae, Pleuronectidae et Soleidae. Ph.D. thesis, Univ. Bretagne Occidentale.

Ekman, S. - 1953. Zoogeography of the sea. Sidgwick and Jackson, London.

García-Rodríguez, M. and A. Esteban. - 2000. Contribution to the knowledge of Citharus linguatula (Linnaeus, 1758) (Osteicthyes: Heterosomata) in the Iberian Mediterranean. Demersal Resources in the Mediterranean. Actes des Colloques IFREMER, 26: 131-140.

Gerking, S.D. - 1994. Feeding Ecology of Fish. San Diego, CA, Academic Press.

Holmes, R.A. and R.N. Gibson. - 1983. A comparison of predatory behaviour in flatfish. Anim. Behav., 31: 1244-1255.

Hyslop, E.J. - 1980. Stomach contents analysis: a review of methods and their application. J. Fish Biol., 17: 415-429.

Kosior, M., J. Kuczynski and W. Grygiel. - 1996. Reproduction of Baltic flounder (Platichthys flesus (L)) in relation to some somatic factors. ICES Counc. Meet. Pap., 25 pp.

Landa, J., N. Pérez and C. Piñeiro. - 2002. Growth patterns of the four spot megrim (Lepidorhombus boscii) in the northeast Atlantic. Fish. Res., 55: 141-152.

Lozán, J.L. - 1992. Sexual differences in food intake, digestive tract size, and growth performance of the dab, Limanda limanda $\mathrm{L}$. Neth. J. Sea Res., 29: 223-227.

Marfin, J.P. and N. Hajji. - 1988. Croissance de Microchirus azevia (Capello, 1867) du sud Marocain. Cybium, 12(2): 123-128.

Marshall, S. and M. Elliott. - 1997. A comparison of univariate and multivariate numerical and graphical techniques for determin- 
ing inter- and intraspecific feeding relationships in estuarine fish. J. Fish Biol., 51: 526-545.

Masson, G. - 1988. Biologie du Flet, Platichthys flesus L. Sur les côtes europeennes. Rap. DEA d'Ecol., 51 pp.

Matallanas, J. - 1982. Estudio del regimen alimentario de Lampanyctus crodilus (Risso, 1810) (Pisces, Myctophidae) en lascostas catalanas (Med. occid.). Téthys, 10: 254-260.

Morte, S., M.J. Redón and A. Sanz-Brau. - 1999. Feeding ecology of two megrims Lepidorhombus boscii and Lepidorhombus whiffiagonis in the western Mediterranean (Gulf of Valencia, Spain). J. Mar. Biol. Ass. U.K., 79: 161-169.

Nielsen, J.G. - 1986a. Citharidae. In: P.J.P. Whithead, M.L. Bauchot, J.C. Hureau, J. Nielsen and E. Tortonese (eds.), Fishes of the North-eastern Atlantic and the Mediterranean, Vol III, pp. 1286. UNESCO.

Nielsen, J.G. - 1986b. Scophthalmidae. In: P.J.P. Whithead, M.L. Bauchot, J.C. Hureau, J. Nielsen and E. Tortonese (eds.), Fishes of the North-eastern Atlantic and the Mediterranean, Vol III, pp. 1287-1293. UNESCO.

Nielsen, J.G. - 1986c. Bothidae. In: P.J.P. Whithead, M.L. Bauchot, J.C. Hureau, J. Nielsen and E. Tortonese (eds.), Fishes of the North-eastern Atlantic and the Mediterranean, Vol III, pp. 1294-1298. UNESCO.

Nielsen, J.G. - 1986d. Pleuronectidae. In: P.J.P. Whithead, M.L. Bauchot, J.C. Hureau, J. Nielsen and E. Tortonese (eds.), Fishes of the North-eastern Atlantic and the Mediterranean, Vol III, pp. 1299-1307. UNESCO.

Pauly, D. - 1994a. A framework for latitudinal comparisons of flatfish recruitment. Neth. J. Sea Res., 32 (2): 107-118.

Pauly, D. - 1994b. On the Sex of Fish and the Gender of Scientists: Essays in Fisheries Science. Fish and Fisheries Series. Chapman and Hall, London.

Pitt, T.K. - 1973. Food of the American plaice (Hippoglossoides platessoides) from the Grand Bank, Newfoundland. J. Fish. Res. Board Can., 30: 1261-1273.

Platell, M.E. and I.C. Potter. - 1998. Distributions, size compositions and diets of two abundant benthic ambush-feeding teleosts in coastal waters of south-western Australia. J. Mar. Biol. Ass. U.K., 78: 587-608.

Quéro, J.C., M. Desoutter and F. Lagardère. - 1986a. Soleidae. In: P.J.P. Whithead, M.L. Bauchot, J.C. Hureau, J. Nielsen and E. Tortonese (eds.), Fishes of the North-eastern Atlantic and the Mediterranean, Vol III, pp.1308-1324. UNESCO.

Quéro, J.C., M. Desoutter and F. Lagardère. - 1986b. Cynoglossidae. In: P.J.P. Whithead, M.L. Bauchot, J.C. Hureau, J. Nielsen and E. Tortonese (eds.), Fishes of the North-eastern Atlantic and the Mediterranean, Vol III, pp. 1325-1328. UNESCO.

Rae, B.B. - 1971. The distribution of flatfishes in Scottish and adjacent waters. Mar. Res. Scotl., 2: 1-19.

Redon, M.J., M.S. Morte and A. Sanz-Brau. - 1994. Feeding habitats of the spotted flounder Citharus linguatula off the eastern coast of Spain. Mar. Biol., 120: 197-291.

Rijnsdorp, A.D. and Ibelings, B. - 1989. Sexual dimorphism in the energetics of reproduction and growth of North Sea plaice,
Pleuronectes platessa L. J. Fish Biol. 35: 401-415.

Robson, S.M., P.A. King, J. Hannan and D. McGrath. - 2000. Age and growth of a sample of four-spot megrim, Lepidorhombus boscii, from off the west coast of Ireland. Biology and Environment: Proc. Royal Irish Acad., 100B(3): 143-148.

Santos, P.T. - 1994. Growth and reproduction of the population of the four-spot megrim (Lepidorhombus bosccii Risso) off the Portuguese coast. Neth. J. Sea Res., 32(3-4): 379-383.

Serrano, A., F. Velasco, I. Olasco and F. Sanchez. - 2003. Macrobenthic crustaceans in the diet of demersal fish in the Bay of Biscay in relation to abundance in the environment. Sarsia, 88: $36-48$.

Shannon, C.E. and W. Weaver. - 1949. The Mathematical Theory of Communication. Urbana, IL: University of Illinois Press.

Sobral, M.P. - 2007. Aspectos relativos à biologia reprodutiva da solha, Platichthys flesus (Linnaeus, 1758), da Ria de Aveiro e litoral adjacente. Tech. Rep., 44: 1-31.

Solemdal, P. - 1967. The effect of salinity on buoyancy, size and development of flounder eggs. Sarsia, 29: 431-442.

Summers, R.W. - 1979. Life cycle and population ecology of the flounder Platichthys flesus (L.) in the Ythan estuary, Scotland. J. Nat. Hist., 13: 703-723.

ter Braak, C.J.F. and P. Smilauer. - 2002. Canoco for Windows Version 4.5. Biometris. Plant Research International, Wageningen.

Türker Çakir, D., B. Bayhan and B. Hossucu. - 2005. Some Parameters of the Population Biology of Spotted Flounder (Citharus linguatula Linnaeus, 1758) in Edremit Bay (North Aegean Sea). Turk. J. Vet. Anim. Sci., 29: 1013-1018.

Vassilopoulou, V. - 2006. Dietary habits of the deep-sea flatfish Lepidorhombus boscii in north-eastern Mediterranean waters. J. Fish Biol., 69: 1202-1220.

Vassilopoulou, V. and I. Ondrias. - 1999. Age and growth of the four-spotted megrim (Lepidorhombus boscii) in eastern Mediterranean waters. J. Mar. Biol. Ass. U.K., 79: 171-178.

Vassilopoulou, V. and C. Papaconstantinou. - 1994. Age, growth and mortality of the spotted flounder (Citharus linguatula Linnaeus, 1758) in the Aegean Sea. Sci. Mar., 58(3): 261-267.

Vianet, R., J.P. Quignard and J.A. Tomasini. - 1989. Age et croissance de quatre poissons pleuronectiformes (flet, turbot, barbue, sole) du Golf du Lion. Evolution de la structure de la sagitta. Cymbium, 13(3): 247-258.

Vinagre, C., S. França, M.J. Costa and H.N. Cabral. - 2005. Niche overlap between juvenile flatfishes, Platichthys flesus and Solea solea, in a southern European estuary and adjacent coastal waters. J. Appl. Ichthyol., 21: 114-120.

Wootton, R.J. - 1998. Feeding. pp. 27-62. In. R.J. Wootton (2nd ed.) Ecology of Teleost Fishes, Kluwer Academic Publishers, The Netherlands.

Zar, J.H. - 1984. Biostatistical Analysis, $2^{\text {nd }}$ edn. Prentice-Hall. New Jersey.

Scient. ed.: E. Macpherson.

Received November 20, 2008. Accepted May 29, 2009.

Published online February 22, 2010. 